direction the result of unconscious observation, and that some animals possessed the first in a pre-eminent de zree? The wonderful faculty hunters posiess of finding their way through immense mountainnus tracts so thickly wooded that one cannot see farther han a few yards at a time, may perhaps be accounted for by this power of unconscious observation alone; but is it so easy to account for a sudden derangement of the sense of direction, and the peculiar distress it occasions, even when there is no ground for alarm on the score of safety? This appears a kind of converse of the instance Mr. Darwin gives of the case of old persons losing their way.

The Walk, Lyme Regis, April 6

Destruction of Rare Birds: White Tom Cats

MANY of our birds are now protected by law, at certain seasons of the year. But unhappily rare visitants are mercilessly killed. Last year a pair of Hoopoes frequented my grounds both in the spring and autumn. It was a great pleasure to see this bird (of which Horapollo wrote that it was worthy to be "the sceptre of the gods on account of its gratitude"), on the lawn, busily searching for insects, or alighting on the surrounding trees. Every lover of nature will sympathise with my household and myself, in our distress that they have been shot; not even for the miserable satisfaction of the mere collector, but far worse, that their plumage might be stuck on a lady's head-gear. To shoot storks, sfoonbills, bee-eaters, hoopoes, \&c., which might be regular visitants and nest here, is a very different thing from securing chance arrivals from remote regions, which could never be naturalised in England.

One of your correspondents wrote recently of the deafness of white Persian tom cats. I possessed such an one for years which was not deaf; another, in a house near me, is not deaf, and I now have a grand fellow, a true Persian, in possession of all his faculties. A neighbour's pussy having walked into the house, with characteristic Oriental hospitality he went to the larder, and selecting a fish which he doubtless thought would be a bonne bouche for his guest, laid it before his friend, and did not himself partake of it.

Trebah, Cornwall, March 3I

C. F.

\section{Phosphorescence in Wood}

If some one would be good enough to give me a little information concerning the following (to me novel) phenomenon, he would oblige.

A heap of sticks intended for firing, lay in a corner of our boiler-house, and among them were some round pieces of Scotch fir (Pinus sylvestris) about 6 or 8 inches in diameter, and 18 inches long. These had been sawn from a pole which had lain out in the wet, and being consequently rather damp, the cut portions were placed in the warm boiler-house to dry. The blocks I speak of appeared quite sound. From the circumference of three or four of them the bark was rubbed off, here and there in patches, and a few chips were broken away from the edges. The fresh surface beneath was covered with a thin layer of the ordinary sticky resin, which so copiously exudes from this and other trees. When it was dark the steward happened to enter the boiler-house, and looking towards the sticks he was surprised to see a pale steady light emitted by some of them. At first he thought it was the reflection of the moon which shone through the window. Closer examination, however, proved: (r) that the moon did not shine on the sticks at all ; (2) that the sticks were self-luminous; (3) that it was only the Scotch fir blocks which emitted any light ; (4) that the light was confined to the resinous surface, exposed beneath the bark and chips; $(5)$ that the surface beneath the chips (that is where more than the bark had been removed) was brightest. The steward carried the block which appeared most brilliant to an outhouse, where it still continued to "shine." He then broke off some small loose chips with his fingers from this block, and each separate chip sent forth the same steady pale light. My informant states that the phenomenon was very "curious." Perhaps this species of phosphorescence may not be unusual after all; but not being well "up" in the subject, I would with your permission, sir, merely ask is it common, and if so, how is it explained in the instance I menion? I may state that the steward gave me all the information. I saw the blocks afterwards but not the curiosity.

Fassaroe Bray

\section{Indices of Journals}

PUBLISHERS of periodicals, scientific or other, issue general indices only after intervals of ten or twenty years. In the ninth or nineteenth year the investigator of bibliography has to turn over every volume, a ftarful was:e of time. I have consulted with the librarian of this University, and the proposal we have to make is that the publishers should send, at least to the libraries, a duplicate copy of the annual index of each journal, or better a revised proof in slips, to be cut up and pasted into a volume which would thus be annually extended for nine years, and superseded in the teuth by the general index. The addition to the expense in a library is very trifling, and a small payment for the extra copies of the indices would protect the publishers against loss.

Glasgow University

JoHN YOUNG

\section{THE DUTCH SOCIETY OF SCIENCES}

THE following account of the history of the Dutch

Society of Sciences at Harlem has been drawn up by the Secretary, E. H. von Baumhauer, for publication in England. It shows the progress of science in Holland, and the great interest taken in its advancement both in that country and abroad, as proved by the award of so many valuable gold medals, and by the recent establishment of a central bureau for the exchange and transmission of books; all which activity is maintained without any of the expense falling on the scientific members.

In the middle of the last century the greater part of the aristocracy of Harlem were desirous of finding recreation in physical experiments and scientific researches. Along with several regents of the town they decided in 1752 to establish a self-supporting society, for the collection of written essays, and the bestowal of prizes on those of meritorious character. At the first meeting, May 21,1752 , the preacher, C. C. H. van $\operatorname{der} \mathrm{Aa}$, was appointed secretary, and many other protectors of the sciences and learned men in other parts of the country, were invited to become members, amongst whom were Musschenbrock, Gambius, Alberti, and others, so that by the end of the year the Society was already formed of twenty-three directors and members. The design was to include all branches of science, and to search for everything necessary for the present and future prosperity of the Republic, both in its internal and external relations, in peace and in war. Even communications on theological subjects were not excluded, treated in such a manner as not to offend Christians of any sect. The motto of the Society was Deo et Patrice. By the help of many wealthy persons the Socicty was enabled to crown several prize essays, published in the transactions. In July 1754 the protectorate was conferred on the young hereditary governor, William Prince of Orange.

Several very eminent native and foreign men became members of the Society, and the first volume of the Transactions was so favourably received that a second edition was necessary. It was also in great part translated into German. The prize questions excited much interest in other countries, so that several were answered by foreigners. Since 1772 an annual programme has been published in both Dutch and French.

After an existence of twenty-five years the Society founded a sub-division, more specially devoted to commerce, agriculture, and industry, under the name of the Commercial Branch. This was the origin of what was afterwards called the Dutch Society for the Promotion of Industry, which in 1877 will celebrate its centenary festival.

The parent institution continued in a flourishing state until I780; but the mournful political situation of the country for some time after that had a most injurious effect, so that the very name of this Society was continually changed. From 1798 it was called the Bavarian Society. King Louis called himself perpetual President of the Royal Society of Sciences ; but in 1820 , by order of the Emperor's Governor, the Prince of Plaisance, the name of the Dutch was again adopted, and has been re- 
tained till now. William I. willingly accepted the protectorate, and his example has been followed by his successors.

The Secretary Van der Aa, who had been the soul of the Society from $175 \mathrm{I}$ to 1794 , was succeeded by the renowned Physical Professor Martinus van Marum, who at his death in 1837 was succeeded by the Professor of Geology, T. G. S. van Breda, who took his dismissal in 1864, when the Professor of Chemistry, E. H. von Baumhauer, was appointed to the office.

From 1754 to 1793 the Society published thirty volumes of Transactions, of which registers by the celebrated T. T. Martinet were issued in 1773 and 1793. These Transactions contain essays on all branches of science, and also many on theology. It was principally through the influence of Van Marum that since then a more predominating share has been taken by physical subjects. From 1799 to 1844 a first series of 24 volumes in octavo, and from I 841 to 1866 a second series of 25 volumes in quarto, and since 1870 a third series of "Physical Transactions" have been published by the Society. In 1802 a volume in octavo of "Mechanical and Mathematical Transactions" was published, and in I821 and 1822 two volumes in octavo of "Philosophical Transactions." From I 815 to I 820 three volumes in octavo on literary and archæological subjects, and since 18512 volumes of "Historical and Literary Transactions" in quarto have been published. The second and third series of "Physical Transactions" are especially distinguished by the memoirs written by the most eminent men in Europe, mostly illustrated by excellent plates.

The revenue of the Society is derived from the interest of capital, for which it is indebted to the kindness of the directors and from the annual subscriptions of the actual directors. It receives no pecuniary assistance whatever from the Government.

With these means the Society endeavours to make known to the world excellent writings on physical subjects, which otherwise wculd be published with difficulty on account of their speciai character and the costliness of the illustrations.

Besides supporting such works, the Society encourages scientific researches, and since I 866 has published a journal in the French language, edited by the Secretary, under the title of "Archives Néerlandaises des Sciences Exactes et Naturelles," of -which already 7 volumes have appeared. This journal is destined to make known to the world all that is produced in the Netherlands and the Dutch possessions related to physical science. This is of great service to the Dutch scientific men, since their researches, being for the most part written in a language so little known generally as the Dutch, would otherwise obtain only a very partial publicity.

The Society is composed of an indefinite number of directors, for the greater part gentlemen of wealth and social importance, who pay an annual contribution of fifty gulden (about four guineas) and manage the finances, which, however, now are especially under the charge of five directors living in Harlem, presided over by the president. There are also sixty native and sixty foreign members, who are chosen in the General Assembly, held on the third Saturday of May, from a list of candidates made by the directors and members. These members pay no contribution whatever, and receive free all the publications of the Society. This membership of the oldest and most important Dutch society is esteemed a great distinction by learned men. The English members are Davidson, Davis, Kirkman, Hooker, Lyell, Owen, Sorby, Tyndall, and Wheatstone. The president of the Society is chosen every three years by the directors. At the present time the office is filled by Baron $F$. W. van Styrum. When a vacancy occurs in the secretaryship, the native members nominate six from amongst themselves from whom the secretary is chosen by the directors. He also acts as treasurer and librarian, and is the only paid officer, living in Harlem in the magnificent building belonging to the Society.

The Society exchanges its publications with almost all the foreign academies and learned institutions, and to facilitate the interchange of books, the Secretary has instituted a central bureau in imitation of the American Smithsonian Institute.

As already named, the Society has regularly published a list of prize questions, the meritorious answering of which is rewarded by a gold medal of the value of about twelve guineas, to which may be added an equal sum or more, in money. At the present time no less than twenty such medals and prizes are offered for an equal number of subjects.

At the centennial festival in 1852 the Society offered a prize of 1000 gulden for the most important work in one of the branches of physics, which should be published during the next four years, and a second of 2,000 gulden for the best in four following years. In the General Assembly of 1857 it was decided that this latter prize should not be bestowed upon anyone, but that $M$. Foucault should be informed that the Society regretted that his communicated discoveries had not happened in the specified time, but would bestow on him the gold medal as a proof of the high value placed on his researches. On the contrary, the first prize was doubled, on account of the difficulty of deciding between two authors of transmitted works, M. A. Decandolle of Geneva, and Herr O. Heer of Zurich, who were both judged to be deserving of the $1, \infty 00$ gulden offered to each.

In the general assembly of 1869 the Society resolved that quite independently of the medals bestowed on crowned prize questions, two new medals should be established, of the intrinsic value of 500 gulden (about 40 guineas), one to bear the name and image of Huygens, and the other those of Boerhaave. These medals will be bestowed alternately every two years on learned men in the country or abroad, who shall be thought by the Society to have made themselves particularly meritorious during the last twenty years in a fixed subdivision of the mathematical and physical sciences, by their researches, discoveries, or inventions. The Huygens medal was to be assigned in 1870 to the branch of physics, and will be assigned in 1874 to chemistry, in 1878 to astronomy, in 1882 to meteorology, and in 1886 to pure and applied mathematics.

The Boerhaave medal was to be assigned in 1872 to geology and mineralogy, and will be assigned in 1878 to botany, in 1880 to zoology, in 1884 to physiology, and in 1888 to anthropology; after which the same order will be repeated over and over again in the case of both medals, so that one medal will be given every twenty years for each of ten different subjects. The judgment is to take place by a Commission to be appointed by the directors, of which Commission the Secretary of the Society is always to be a member. The award is to be made in the General Assembly, in accordance with the pre-advice of the Commission, accompanied with a particular account of the motives which have led to the choice.

The first Huygens medal was awarded in 1870 to Rodolph Julius Emmanuel Clausius, Professor at the University of Bonn, as founder of the mechanical theory of heat; and in 1872 the first Boerhaave medal was given to Henry Clifton Sorby of Sheffield, for having made himself particularly meritorious by his microscopical researches in connection with geology and mineralogy, during the last twenty years.

The portrait of Huygens was taken from a copper-plate engraving by Edelink, and that of Boerhaave, from an oil painting by Troost, now in the Academy at Leiden. Independent of their size ( 3 in. in diameter, 9 oz. troy) both these medals are most creditable to all parties concerned as fine works of art. 